\title{
Coexistence of Danaus chrysippus (Linnaeus, I758) (Lepi- doptera Nymphalidae) on the Milkweed Pergularia tomentosa L. (Asclepiadaceae) in Aïn Naga (Biskra, Algeria)
}

\author{
Abdenour Kheloufi, Lahouaria Mounia Mansouri* \& Rabeh Belatreche \\ Department of Ecology and Environment, Faculty of Natural and Life Sciences, University of Batna 2, 05000 Batna, \\ Algeria \\ ${ }^{*}$ Corresponding author, e-mail: lhouaria.mansouri@gmail.com
}

\begin{abstract}
A butterfly species, Danaus chrysippus (Linnaeus, 1758) (Lepidoptera Nymphalidae), also known as African Queen, is recorded for the first time in the arid region of Aïn Naga (Biskra, Algeria). Adults of $D$. chrysippus were recorded in a survey from October 2018 to February 2019 on their host plant Pergularia tomentosa (Milkweed) (Asclepiadaceae). Additional data on the life cycle and behavior of this species are given.
\end{abstract}

KEY WORDS Butterfly; biodiversity; bioconservation; Danainae; distribution.

Received 24.06.2019; accepted 25.10.2019; published online 31.10.2019

\section{INTRODUCTION}

Danaus chrysippus (Linnaeus, 1758), also known as African Queen, is a butterfly belonging to the family Nymphalidae that includes about 7000 species worldwide. It is a migrant butterfly belonging to Danainae, a subfamily of Nymphalidae tropical butterflies with a complex biology (Francke, 1989).

Danaus chrysippus is widespread in Africa, southern Europe (Canary Islands, coastal Mediterranean regions, Turkey), Saudi Arabia, tropical Asia, Australia and New Zealand.

Danaus chrysippus has considerably increased and extended its range in the North African coastal regions, probably due to warmer climates, and from there has colonised parts of the south coast of Spain, Corsica, Sardinia, Sicily, Italy, Malta, and Greece (Burton, 2001).

This species is multivoltine and lives in open areas, sometimes even degraded, and near gardens or cultivated areas (Perković, 2006). The biology of this species is influenced by the availability of larval foodplants. Altough it is polyphagous, its larvae feed on plants which contain cardenolides, expecially Asclepiadaceae, Apocynaceae and Moraceae (Ackery \& Vane-Wright, 1984).

There is a huge literature surrounding this species. Particularly, taxonomic studies are reported by Seitz' (1927) and Munroe (1961), Downey (1962), Pierre (1984). Ackery \& Vane-Wright (1984) use the host plant relations as data for butterflies classification. Igarashi (1984) classified the Papilionidae mainly based on the morphology of their immature stages.

However, there is no reason to suppose that host plant associations can be used for taxonomy with respect to morphological characters (Ackery, 1988).

In this work, based on photographs of the study area during the period October 2018-February 2019 , we expose and confirm the coexistence of $D$. 
chrysippus on the Milkweed Pergularia tomentosa L. (Asclepiadaceae) in the arid region of Aïn Naga (Biskra, Algeria).

\section{MATERIAL AND METHODS}

In our research in Aïn Naga (Biskra, Algeria) (Fig. 1) during a period from October 2018 and February 2019, our purpose was to realize a survey on the Milkweed Pergularia tomentosa (population density, height, leaves number, pods and seeds number, etc...) and collect some seeds to test its seed germination under drought conditions under greenhouse.

Our study area is about $320 \mathrm{~m} \mathrm{x} 170 \mathrm{~m}$ so about 5 ha with $>50$ individuals of $P$. tomentosa per 1000 $\mathrm{m}^{2}$. An average of $20{ }^{\circ} \mathrm{C}$ of temperature and $25 \%$ of humidity was recorded during this period between $2 \mathrm{~h} 00$ and $4 \mathrm{~h} 00 \mathrm{pm}$.

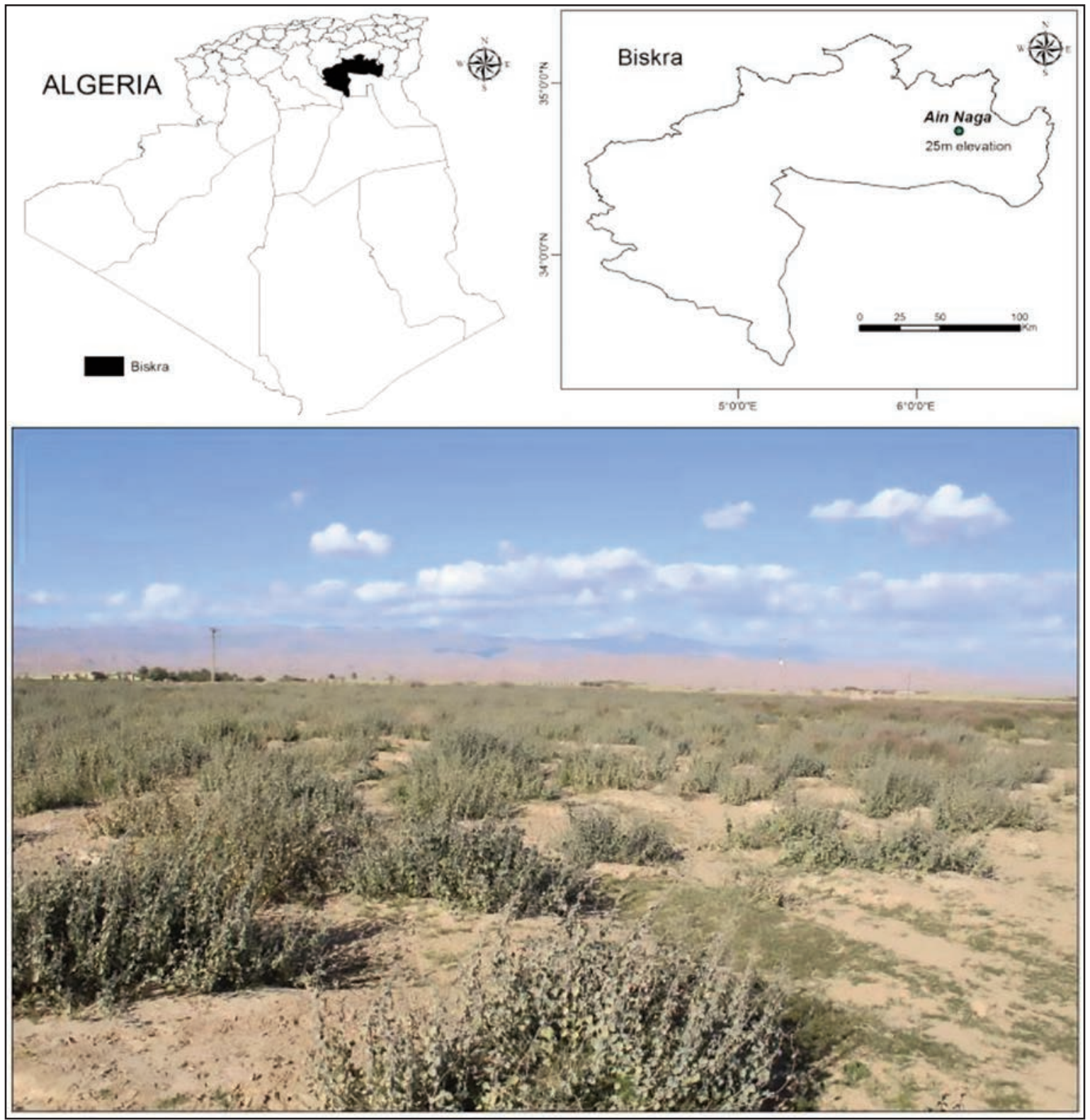

Figure 1. Study area where Danaus chrysippus was observed (Aïn Naga, Biskra, Algeria). 
During this survey, several specimens of $D$. chrysippus were observed especially on this plant species. Thus, we decided to take pictures with a Coolpix Nikon P610 and send them to the MLMP (The Monarch Larva Monitoring Project, University of Minnesota) for identification, confirming that the butterfly is $D$. chrysippus.

\section{RESULTS}

During the study period (October 2018-February 2019) we studied the Danaus Kluk, 1802 populations found in the arid region of Ain Naga (Biskra, Algeria) in relation to the presence of P. tomentosa.

Every week we recorded about 18-23 specimens of this butterfly (both sexes) and we found a coexistence between $D$. chrysippus and its host plant $P$. tomentosa. Coexistence was justified by the stages of butterfly development (larval, pupal and adult stages) on this milkweed (Fig. 2).

\section{DISCUSSION}

Biological cycle of the butterflies of the subfamily Danainae is linked mainly to Asclepiadaceae, Apocinaceae and Moraceae but also to Convolvulaceae, Euphorbiaceae, Sapindaceae, and Plumbaginaceae (Ackery \& Vane-Wright, 1984). Particularly, the larvae of $D$. chrysippus feed mainly on Asclepiadaceae, from which they store cardenolides (MEBS et al., 2005) to escape predators.

Danainae have a great diversity among almost all factors relating to ecology of the host plants with interesting correlations (Brower et al., 2010).

Currently, there has been no up-to-date review of the chemoecology of Danaini since Ackery \& Vane-Wright (1984). This work has glossed also over a number of supposed exceptions and problems due to under-sampling, insufficient chemical analyses, and unreliable identifications; moreover, many species were not included in this study because of the difficulty of obtaining living specimens.

Another very important plant relationship for most Danaini, including $D$. chrysippus, is adult pharmacophagy, notably, the adult uptake of pyrrolizidine alkaloids from various plants that are not larval hosts. Ackery \& Vane-Wright (1984) have records of adult danaines attracted to over thirty families of flowering plants, bur many of these are certainly only nectar sources. The main host plants of Danaus are numerous asclepiads, a group now placed within the Apocynaceae. The utilization of Panowla (Apocynaceae) both as a larval foodplant and adult attractant has led to the suggestion that Parsonsia might represent the ancestral foodplant of the Danainae (Edgar et al., 1974; Edgar, 1984).

With respect to D. chrysippus in Algeria, Tennent (1996) notes that it has been "recorded commonly on Pergularia tomentosa and Cynanchum acutum", and, probably, also on Calotropis procera. According to Samraoui (1996), the breeding status of $D$. chrysippus in the Algerian Sahara is confirmed and its larval foodplant on Calotropis procera is reported on. Moreover, the species has apparently increased in numbers and considerably expanded its range. However, in the last two decades, no study has been able to determine a specific range and distribution of this species in Algeria. There are several inventories in some arid and Saharan region of Algeria that include observations of very few individuals.

Borgo et al. (1992) reported that the distribution of D. chrysippus in Italy from 1986-1990 was linked to the warm conditions.

The climatic data in the region of Biskra during the period 1980-2018 taken from the universal climate data site "Tutiempo" (www.tutiempo.net) shows that the average annual temperature is 22.7 ${ }^{\circ} \mathrm{C}$, the maximum annual average is $28.4{ }^{\circ} \mathrm{C}$, and the minimum annual average is $16.9^{\circ} \mathrm{C}$. The total annual precipitation is $160.6 \mathrm{~mm}$ with only 30 days of rainy days.

\section{CONCLUSIONS}

In conclusion, these brief observations on the presence of Danaus in Algeria and its trophic relations with Pergularia constitute a further contribution to the biology of this interesting butterfly.

We need more data and information on this butterfly in Algeria (distribution and density) to consider it a vulnerable or endangered species, but it is important to point out these observations to try to protect its habitat in this new study area. 

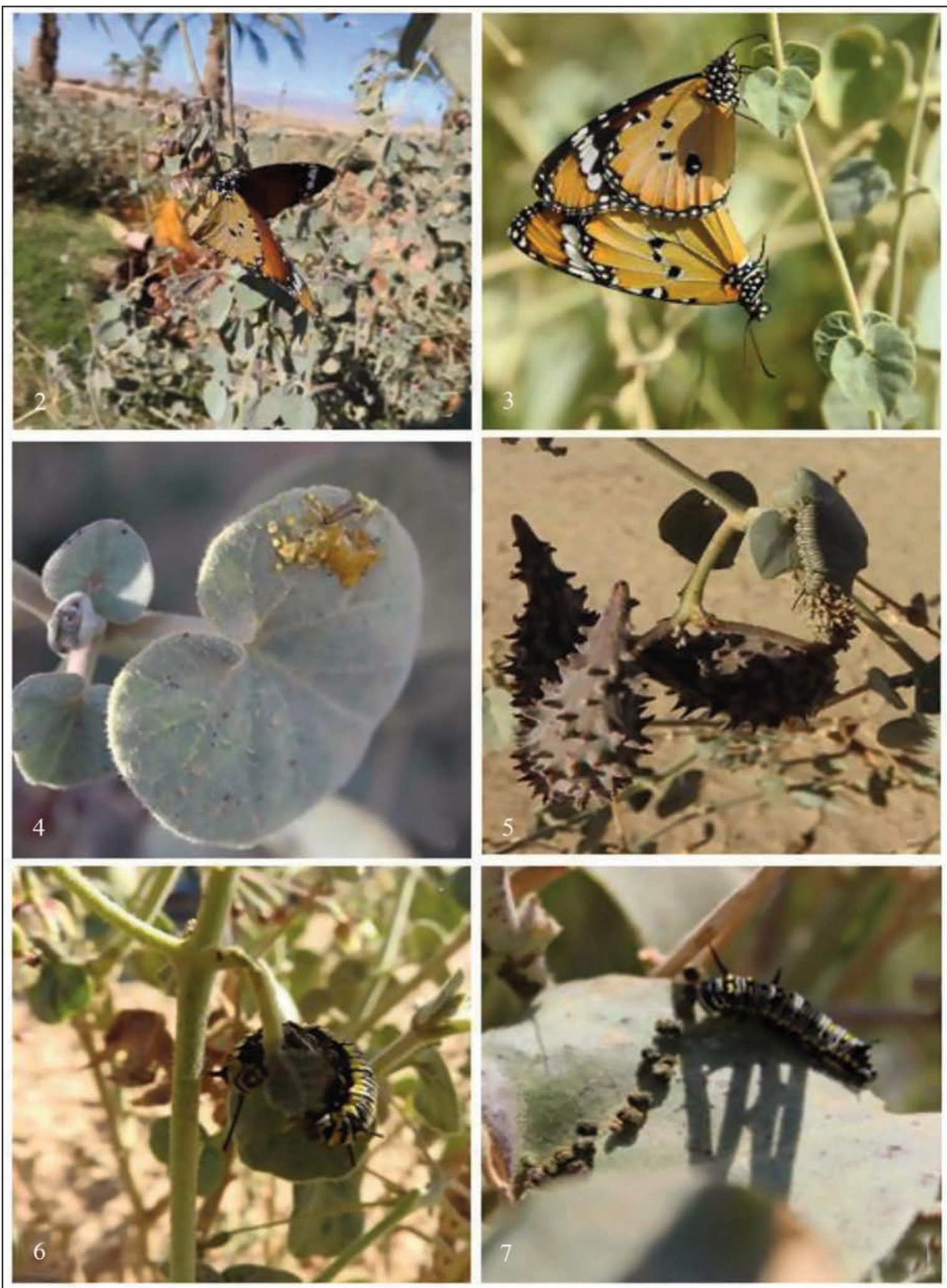

Figures 2-7. Danaus chrysippus and Pergularia tomentosa from Aïn Naga (Algeria). Fig. 2. Adult butterfly feedingnectar flower. Fig. 3. Butterflies mating. Fig. 4. Butterfly eggs hatching. Figs. 5-7. Leaf Feeding Caterpillars (larvae). 

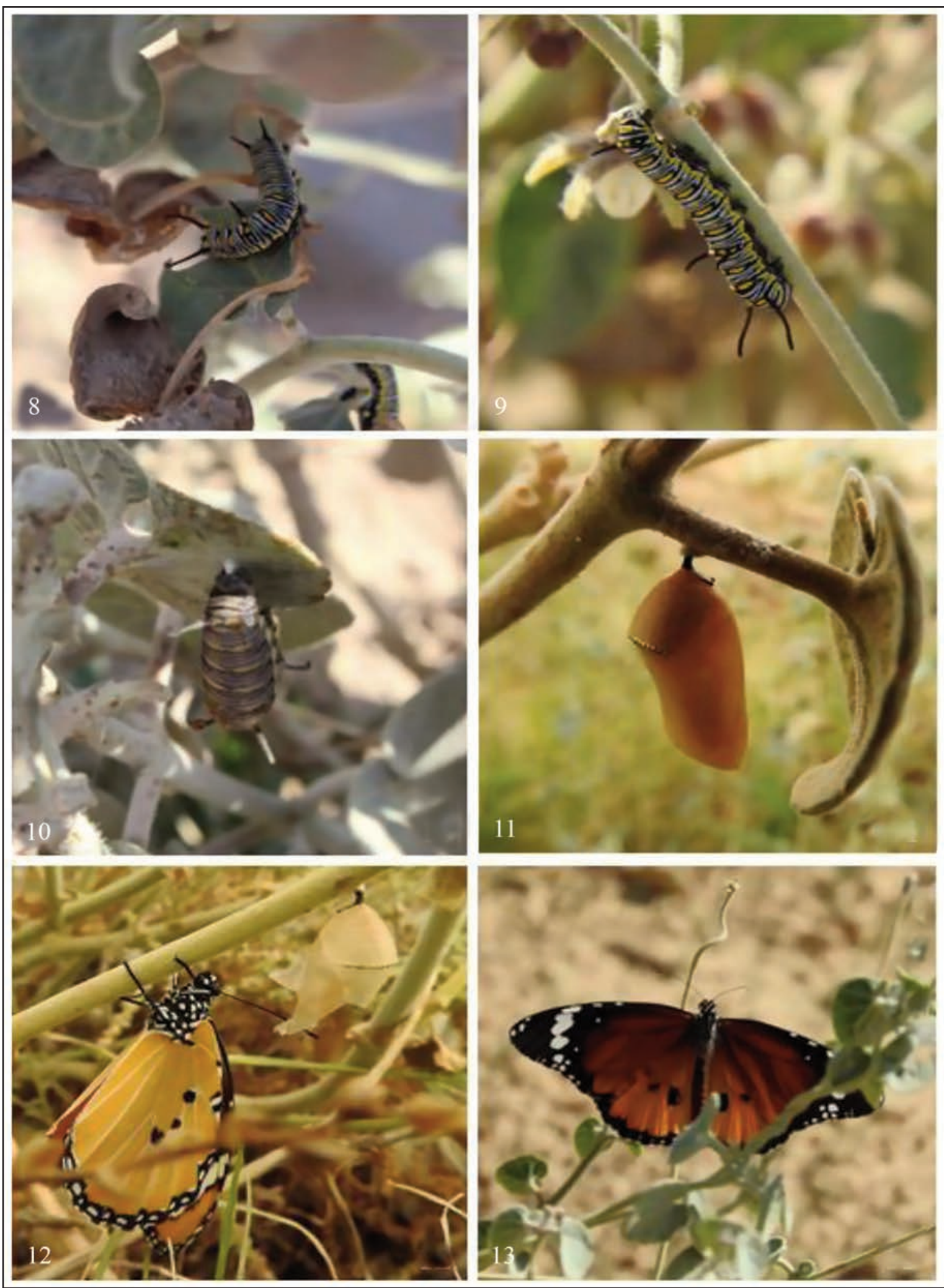

Figures 8-13. Danaus chrysippus and Pergularia tomentosa from Aïn Naga (Algeria). Figs. 8, 9. Caterpillars. Fig. 10. Larvae preparing for pupa stage. Fig. 11. Pupa. Fig. 12. Butterfly emerging from a chrysalis. Fig. 13. Adult butterfly. 


\section{ACKNOWLEDGENENTS}

The authors are very grateful to Dick Vane-Wright (Affiliate Member, Durrell Institute of Conservation and Ecology (DICE), University of Kent, Canterbury CT2 7NR), Katie-Lyn Bunney (Program Coordinator - Monarchs in the Classroom, The University of Minnesota Monarch Lab) and Karen Oberhauser (Director, University of WisconsinMadison Arboretum, The University of Minnesota Monarch Lab) for their help in confirming the butterfly identification and taxonomy. We thank also Arvind Singh $(\mathrm{PhD}$ and Researcher at the Department of Botany, Banaras Hindu University Varanasi, India) for helping us confirming the identification of Pergularia tomentosa.

\section{REFERENCES}

Ackery P.R., 1988. Hostplants and classification: a review of nymphalid butterflies. Biological Journal of the Linnean Society, 33: 95-203.

Ackery P.R. \& Vane-Wright R.I., 1984. Milkweed butterflies, their cladistics and biology: being an account of the natural history of the Danainae, a subfamily of the Lepidoptera, Nymphalidae. British Museum (Natural History); Ithaca, N.Y.: Comstock Pub. Associates, $425 \mathrm{pp}$.

Ackery P.R. \& Vane-Wright R.I., 1985. Patterns of plant utilization by danaine butterflies. Proceedings of the 3rd Congress of European Lepidopterology, Cambridge, pp. 3-6.

Borgo E., Cassulo L., Rainieri V. \& Zilli A., 1992. On the expansion of Danaus chrysippus (Linnaeus, 1758) during the last decade in Italy. Atalanta, 23: 407-410.

Brower A.V., Wahlberg N., Ogawa J.R., Boppré M. \& Vane-Wright R.I., 2010. Phylogenetic relationships among genera of danaine butterflies (Lepidoptera: Nymphalidae) as implied by morphology and DNA sequences. Systematics and Biodiversity, 8: 75-89. https://doi.org/10.1080/14772001003626814

Burton J.F., 2003. The apparent influence of climatic change on recent changes of range by European insects (Lepidoptera, Orthoptera). Proceedings 13th international colloquium European Invertebrate Survey, Leiden, 2-5 September 2001, pp. 13-21.

Downey J.C., 1962. Host-plant relations as data for butterfly classification. Systematic Zoology, 11: 150159.

Edgar J.A., 1984. Parsonsieae: ancestral larval foodplants of the Danainae and Ithomiinae. In: Vane-Wright R.I. \& Ackery P.R. (Eds.), The Biology of Butterflies. Academic Press, New York, pp. 91-93.

Edgar J.A., Culvenor C.C.J \& Pliske T.E., 1974. Coevolution of danaid butterflies and their host plants. Nature, 250: 646-648.

Francke W., 1989. Terpenoids from bark beetles, solitary bees and danaine butterflies. Pure and Applied Chemistry, 61: 539-542.

Igarashi S., 1984. The classification of the Papilionidae mainly based on the morphology of their immature stages. Tyo To Ga, 34: 41-96.

Mebs D., Reuss E. \& Schneider M., 2005. Studies on the cardenolide sequestration in African milkweed butterflies (Danaidae). Toxicon, 45: 581-584. https:// doi.org/10.1016/j.toxicon.2004.12.017

Munroe E.G., 1961. The classification of the Papilionidae (Lepidoptera). The Canadian Entomologist (Suppl.), 17: $1-51$

Perković D., 2006. Danaus chrysippus (Linnaeus, 1758) (Lepidoptera, Nymphalidae, Danainae), a new species in the fauna of Croatia. Natura Croatica, 15: 6164.

Pierre J., 1984. Systématique Evolutive, Cladistique et Mimétisme chez les lépidoptères du genre Acraea (Nymphalides). PhD thesis, University de Paris, France.

Samraoui B., 1996. Breeding status and range expansion of Danaus chrysippus (Linnaeus, 1758) in the Algerian Sahara (Lepidoptera: Nymphalidae Danainae). Nota Lepidopterologica, 19: 261-263.

Seitz A., 1927. Macrolepidoptera of the World. Vol. 9. Oriental and Australian Rhopalocera. Stuttgart: Alfred Kernen, 766 pp. + plates.

Tennent W.J., 1996. The Butterflies of Morocco, Algeria and Tunisia. Wallingford, Oxon, 253 pp. 